\title{
Deoxyribonucleic Acid of Mycobacterium lepraemurium: Its Genome Size, Base Ratio, and Homology with Those of Other Mycobacteria
}

\author{
T. IMAEDA, ${ }^{1}$ L. BARKSDALE, ${ }^{2}$ AND W. F. KIRCHHEIMER ${ }^{3}$
}

Department of Microbiology, University of Medicine and Dentistry of New Jersey, New Jersey Medical School, Newark, New Jersey 07103 ${ }^{1}$; Department of Microbiology, New York University School of Medicine and Medical Center, New York, New York 10016²; and National Hansen's Disease Center, Carville, Louisiana $70721^{3}$

\begin{abstract}
Deoxyribonucleic acid of Mycobacterium lepraemurium grown in mice was isolated and analyzed spectrophotometrically. The genome molecular weight and guanine-plus-cytosine content of this $M$. lepraemurium deoxyribonucleic acid were $1.8 \times 10^{9}$ and $65.5 \mathrm{~mol} \%$, respectively. Among selected strains of mycobacterial species, four strains of Mycobacterium avium showed the highest degree of deoxyribonucleic acid homology ( 74.2 to $92.9 \%$ ) with $M$. lepraemurium, suggesting a close genetic relatedness.
\end{abstract}

Although Mycobacterium lepraemurium is difficult to cultivate in vitro, analyses of masses of this bacterium produced in mice have indicated that the ultrastructure of its cell wall and the chemical structure of a mycolic acid-arabinogalactan-peptidoglycan complex are characteristic of Mycobacterium (1-3, 7, 15). Additional evidence for interrelatedness between $M$. lepraemurium and other mycobacteria has come from serological cross-reactions $(4,8,11,14)$ and patterns of biochemical tests (13) established for organisms grown in vivo or in vitro or both. However, until now there has been no information concerning the deoxyribonucleic acid (DNA) of $M$. lepraemurium: the size of its genome, its guanine-plus-cytosine $(\mathrm{G}+\mathrm{C})$ content, or the extent of homology between its DNA and DNAs of other mycobacteria. In this paper we provide such information derived from spectrophotometric studies of DNA from $M$. lepraemurium, both free and in association with DNAs from other species of Mycobacterium.

The bacterial strains used in this study and their sources and culture media are listed in Table 1. The preparation of DNA samples from bacterial cells grown in vivo or in vitro, the determination of the melting temperature for calculation of the $\mathrm{G}+\mathrm{C}$ content, and the conditions for DNA-DNA reassociation for estimation of the genome size and DNA homology were as described recently (6). Briefly, DNA samples obtained by phenol-chloroform extraction were further treated with cetyltrimethylammonium bromide to remove the polysaccharides which interfere with DNA-DNA reassociation (5). The cetyltrimethylammonium bromide treatment was repeated until the ratio of absorbance at $260 \mathrm{~nm}$ to absorbance at $230 \mathrm{~nm}$ of a DNA solution in $0.1 \times \mathrm{SSC}(0.015 \mathrm{M} \mathrm{NaCl}$ plus 0.0015 $M$ sodium citrate) was greater than 2.0 . The purified DNA samples were dissolved in $0.1 \times$ SSC, sheared by passage either through a 26gauge needle or through a Ribi cell fractionator at $15,000 \mathrm{lb} / \mathrm{in}^{2}$, and stored at $-20^{\circ} \mathrm{C}$. The melting temperatures of various DNA samples in $0.1 \times \mathrm{SSC}$ and the $\mathrm{C}_{0} \mathrm{t}_{0.5}$ values in $6 \times \mathrm{SSC}$ containing $25 \%$ (vol/vol) formamide were determined spectrophotometrically with a Gilford model 2600 system equipped with thermal cuvettes and a thermoprogrammer. The DNA of Escherichia coli K-12 ATCC 23724 was used as a standard (genome molecular weight, $2.5 \times$ $10^{9}$ ).

Table 1 shows the results of a comparison of a DNA sample from $M$. lepraemurium with the DNAs of various species representing $M$. tuberculosis and nontuberculous mycobacteria. With the exception of $M$. leprae, the $\mathrm{G}+\mathrm{C}$ contents of the strains examined ranged from 61.7 to 74.1 mol\%. The genome molecular weights ranged from $1.7 \times 10^{y}$ to $3.0 \times 10^{9}$. Strains characterized by slowness of growth in vitro contained smaller genomes (e.g., $M$. bovis BCG and $M$. lepraemurium). In this connection, reference should be made to our previous observation that the genome molecular weight of $M$. leprae grown in armadillos is $1.3 \times 10^{9}$ (Table 1). Therefore, a relationship may exist between genome size and biosynthetic ability as reflected by rate of replication in vitro.

Of the mycobacterial strains tested, $M$. leprae showed the lowest degree of DNA homology with $M$. lepraemurium, as reported previously (6). In contrast, four strains of $M$. avium showed 
TABLE 1. Genome size, base ratio, and DNA homology between $M$. lepraemurium and selected mycobacteria

\begin{tabular}{|c|c|c|c|}
\hline Organism $^{a}$ & $\underset{\left(\times 10^{9}\right)^{b}}{\text { Genome mol wt }}$ & $\begin{array}{c}\mathrm{G}+\mathrm{C} \text { ratio } \\
(\mathrm{mol} \%)^{c}\end{array}$ & $\begin{array}{l}\text { Homology with } \mathrm{M}_{\text {. }} \\
\text { lepraemurium }(\%)^{b}\end{array}$ \\
\hline M. lepraemurium Hawaiian & $1.8 \pm 0.1^{d}$ & $65.5 \pm 0.0^{d}$ & 100 \\
\hline M. avium TMC $701^{e}$ & $2.6 \pm 0.1$ & $74.1 \pm 0.1$ & $92.9 \pm 0.8$ \\
\hline M. avium TMC 706 & $2.3 \pm 0.1^{d}$ & $71.5 \pm 0.1^{d}$ & $87.7 \pm 3.1$ \\
\hline M. avium TMC 721 & $2.6 \pm 0.1$ & $73.9 \pm 0.1$ & $91.7 \pm 2.8$ \\
\hline M. avium ATCC $19421^{f}$ & $2.1 \pm 0.0$ & $69.6 \pm 0.1$ & $74.2 \pm 4.1$ \\
\hline M. intracellulare TMC 1403 & $2.5 \pm 0.0$ & $65.3 \pm 0.1$ & $53.7 \pm 1.7$ \\
\hline M. intracellulare TMC 1406 & $2.0 \pm 0.0^{d}$ & $68.6 \pm 0.0^{c}$ & $44.1 \pm 4.3$ \\
\hline M. scrofulaceum TMC 1302 & $2.8 \pm 0.0$ & $66.1 \pm 0.1$ & $50.5 \pm 2.2$ \\
\hline M. scrofulaceum TMC 1323 & $2.4 \pm 0.1^{d}$ & $66.1 \pm 0.0^{d}$ & $48.8 \pm 0.8$ \\
\hline M. tuberculosis TMC 201 & $2.0 \pm 0.0$ & $63.3 \pm 0.1$ & $51.1 \pm 2.2$ \\
\hline M. tuberculosis TMC 327 & $2.1 \pm 0.1^{d}$ & $63.3 \pm 0.0^{d}$ & $55.9 \pm 0.5$ \\
\hline M. tuberculosis ${ }^{g}$ & $2.1 \pm 0.0$ & $63.5 \pm 0.1$ & $48.5 \pm 3.6$ \\
\hline M. kansasii TMC 1204 & $3.0 \pm 0.0^{d}$ & $68.8 \pm 0.0^{d}$ & $46.3 \pm 2.5$ \\
\hline M. marinum TMC 1218 & $2.5 \pm 0.1^{d}$ & $67.9 \pm 0.1^{d}$ & $49.8 \pm 3.0$ \\
\hline$M$. bovis TMC 410 & $2.9 \pm 0.0$ & $68.7 \pm 0.0$ & $37.6 \pm 1.5$ \\
\hline M. bovis TMC 1011 (BCG) & $1.9 \pm 0.0$ & $65.9 \pm 0.1$ & $37.3 \pm 3.7$ \\
\hline M. vaccae TMC 1526 & $2.5 \pm 0.1$ & $68.5 \pm 0.1$ & $34.7 \pm 3.8$ \\
\hline M. gordonae TMC 1324 & $2.8 \pm 0.1^{d}$ & $63.3 \pm 0.0^{d}$ & $31.0 \pm 2.3$ \\
\hline M. chelonei TMC 1544 & $2.5 \pm 0.0^{d}$ & $61.7 \pm 0.1^{d}$ & $29.5 \pm 1.4$ \\
\hline M. fortuitum TMC 1529 & $2.7 \pm 0.1$ & $68.1 \pm 0.1$ & $39.2 \pm 3.6$ \\
\hline M. smegmatis ATCC 607 & $3.0 \pm 0.1$ & $68.5 \pm 0.0$ & $48.9 \pm 2.5$ \\
\hline M. leprae & $1.3 \pm 0.0^{d}$ & $55.8 \pm 0.1^{d}$ & $20.2 \pm 2.3^{d}$ \\
\hline
\end{tabular}

${ }^{a} M$. lepraemurium was isolated from spleens and mesenteric nodules of infected Swiss white mice as previously described $(6,7)$. $M$. leprae was isolated from spleen tissues of two armadillos infected with $M$. leprae of human origin. The infected tissues were prepared at the National Hansen's Disease Center and were supplied through the National Institute of Allergy and Infectious Diseases. Other mycobacterial strains were grown in Middlebrook $7 \mathrm{H} 9$ medium (Difco Laboratories) supplemented with $0.5 \%$ bovine serum albumin fraction $\mathrm{V}$ (Sigma Chemical Co.).

$b$ Average of six assays.

c Average of three to six assays.

${ }^{d}$ Data from reference 6.

e TMC, Trudeau Collection of Certified Mycobacteria Mycobacterial Culture Collection (9). These strains were prepared at the National Jewish Hospital and were supplied through the National Institute of Allergy and Infectious Diseases.

${ }^{f}$ ATCC, American Type Culture Collection, Rockville, Md.

$g$ Isolated from a patient with pulmonary tuberculosis in the University of Medicine and Dentistry of New Jersey Hospital.

the highest degrees of DNA homology with $M$. lepraemurium, ranging from 74.2 to $92.9 \%$. Such a close genetic relatedness between $M$. avium and $M$. lepraemurium has already been suggested on the basis of common antigens $(4,14)$. However, other members of the $M$. avium-M. intracellulare-M. scrofulaceum complex showed significantly lower degrees of DNA homology with $M$. lepraemurium. Although the $\mathrm{G}+\mathrm{C}$ content of $M$. lepraemurium is lower than the $\mathrm{G}+\mathrm{C}$ contents of $M$. avium strains, the present study suggests that these organisms belong to the same subgroup within the $M$. avium$M$. intracellulare- $M$. scrofulaceum complex.

Three strains of $M$. tuberculosis, which reportedly show the highest similarity in various biochemical properties to $M$. lepraemurium grown in vitro (13), are not closely related to the latter as far as DNA homology is concerned. This disagreement may be due to the phenotypic expression of $M$. lepraemurium grown in vitro or to the difference in strains used. Since our attempts to grow $M$. lepraemurium in both egg yolk medium (12) and NC-5 liquid medium (10) have been unsuccessful, a comparative analysis of the DNAs contained in this organism grown in vitro and in vivo was not possible in the present study.

This work was supported by grants from the World Health Organization and the Heiser Program for Research in Leprosy.

\section{REPRINT REQUESTS}

Address reprint requests to: $T$. Imaeda, Department of Microbiology, University of Medicine and Dentistry of New Jersey, New Jersey Medical School, 100 Bergen Street, Newark, NJ 07103. 


\section{LITERATURE CITED}

1. Azuma, I., Y. Yamamura, Y. Tanaka, K. Kosaka, T. Mori, and T. Itoh. 1973. Cell walls of Mycobacterium lepraemurium strain Hawaii. J. Bacteriol. 113:515-518.

2. Cummins, C. S., G. Atfield, R. J. W. Rees, and R. C. Valentine. 1967. Cell wall composition in Mycobacterium lepraemurium. J. Gen. Microbiol. 49:377-384.

3. Draper, P. 1971. The walls of Mycobacterium lepraemurium: chemistry and ultrastructure. J. Gen. Microbiol. 69:313-324.

4. Fukui, Y., T. Mori, K. Kosaka, S. Nishimura, and M. Yoneda. 1966. Antigenic structure of Mycobacterium lepraemurium. I. Presence of avian type antigen in strains of M. lepraemurium. Biken J. 9:63-75.

5. Hill, E. B., L. G. Wayne, and W. M. Gross. 1972. Purification of mycobacterial deoxyribonucleic acid. J. Bacteriol. 112:1033-1039.

6. Imaeda, T., W. F. Kirchheimer, and L. Barksdale. 1982. DNA isolated from Mycobacterium leprae: genome size, base ratio, and homology with other related bacteria as determined by optical DNA-DNA reassociation. J. Bacteriol. 150:414-417.

7. Kanetsuna, F., T. Imaeda, and F. San Blas. 1968. Chemical analyses of the cell wall of the murine leprosy bacillus. J. Bacteriol. 96:860-861.

8. Kronvall, G., O. Closs, and G. Bjune. 1977. Common antigen of Mycobacterium leprae, $M$. lepraemurium, $M$. avium, and $M$. fortuitum in comparative studies using two different types of antisera. Infect. Immun. 16:542-546.

9. Lefford, M. J. (ed.). 1980. Trudeau Collection of Certified Mycobacteria. Mycobacterial culture collection. Publication 80-289. National Institutes of Health, Bethesda, Md.

10. Nakamura, M. 1974. Quantitative multiplication of Mycobacterium lepraemurium in a cell-free liquid medium (NC5). J. Gen. Microbiol. 82:385-391.

11. Navalkar, R. G., R. R. Dalvi, and P. J. Patel. 1973. Antigenic evaluation of Mycobacterium lepraemurium. J. Med. Microbiol. 8:177-181.

12. Ogawa, T., and K. Motomura. 1970. Studies on murine leprosy bacillus. I. Attempt to cultivate in vitro the Hawaiian strain of Mycobacterium lepraemurium. Kitasato Arch. Exp. Med. 43:65-80.

13. Saito, H., K. Yamaoka, and K. Kiyotani. 1976. In vitro properties of Mycobacterium lepraemurium strain Keishicho. Int. J. Syst. Bacteriol. 25:111-115.

14. Stanford, J. L. 1973. An immunodiffusion analysis of Mycobacterium lepraemurium Marchoux and Sorel. J. Med. Microbiol. 6:435-439.

15. Yamamoto, T., M. Nishiura, N. Harada, and T. Imaeda. 1958. Electron microscopy of Mycobacterium lepraemurium in the murine leprosy lesions by ultra-thin sectioning. Int. J. Lepr. 26:111-114. 